\title{
Tempo
}

http://journals.cambridge.org/TEM

Additional services for Tempo:

Email alerts: Click here

Subscriptions: Click here

Commercial reprints: Click here

Terms of use : $\underline{\text { Click here }}$

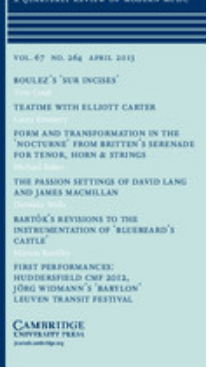

\section{Ligeti the Postmodernist?}

Mike Searby

Tempo / Issue 199 / January 1997, pp 9 - 15

DOI: 10.1017/S0040298200005544, Published online: 23 November 2009

Link to this article: http://journals.cambridge.org/abstract S0040298200005544

How to cite this article:

Mike Searby (1997). Ligeti the Postmodernist?. Tempo, pp 9-15 doi:10.1017/S0040298200005544

Request Permissions : $\underline{\text { Click here }}$ 


\section{Mike Searby}

\section{Ligeti the Postmodernist?}

The stylistic changes in György Ligeti's music since 1960 have in some ways mirrored those in the wider contemporary music world. In his music of the 1960s he displays an experimental and systematic approach to the exploration of sound matter which can also be seen in the contemporaneous music of composers such as Xenakis, Penderecki and Stockhausen. In the 1970s his music shows a more eclectic approach, particularly the opera Le Grand Macabre (1974-7) in which there is much plundering of past styles such as allusions to Monteverdi, Rossini, and Verdi. From this work onward there would appear to be a complete break from the approach in his works on the 1960s.

This softening of the avant garde, modernist stance can also be identified in the music of Ligeti's contemporaries, such as Berio, Xenakis, Maxwell Davies, and Penderecki. ${ }^{1}$ Ligeti's music of the 1980s and 1990s has continued evolving towards greater approachability and an almost tonal or modal (or at least, in his words, "nonatonal' $)^{2}$ language. The general trend of contemporary music in the last 15 years seems to consist of a gradual shift away from a 'modernist' and atonal approach, towards an unashamedly 'postmodernist' and tonal one.

Stephen Taylor, in his study of Ligeti's later music, asks some pertinent questions:

... has the new music in fact simply returned to Ligeti's old style, before he left Hungary? Has Ligeti, in spite of all his protestations to the contrary, gone 'retro'?]

There are some superficial resemblances between Ligeti's 'Hungarian' works, such as the String Quartet No.1 (1953-4), and his recent music: not least the rediscovery of Bartókian stylistic features, particularly in the rhythms of Ligeti's recent compositions. Bartók's music had a pre-

${ }^{1}$ Penderecki has gone much further towards a tonal language composing in a kind of sub-Brucknerian style from the 1970s onwards.

${ }^{2}$ Szzitha, T. 'A Conversation with György Ligeti', Hungarian Music Quarterly, Vol 3, pt1, 1992, p.15.

${ }^{3}$ Taylor, S., The Lamento Motif: Metamorphosis in Ligeti's Late Style, DMA, Cornell University, 1994, p.18. eminent influence on Ligeti in his formative years:

Bartók remained my idol until 1950, and he continued to be very important [to] me even after I left the country in $1956 .{ }^{4}$

Ligeti himself considers that Bartók's influence has returned in his music:

Ever since the 1980s I have experienced a kind of return to Bartók, especially as far as the Piano Concerto is concerned. ${ }^{5}$

The resulting music, however, is very different to his Bartók-tinged music of the 1950s because it shows a synthesis of materials from the 1960s with tonal/modal elements and new ideas. These new ideas include Sub-Saharan and Caribbean polyrhythms, fractal geometry (although admittedly it is difficult to identify this feature clearly), and the player-piano music of the American composer Conlon Nancarrow. Ligeti's recent music does show elements of past styles and his attitude to the avant garde seems to have changed:

My rejection of avant garde music also lays me open to attacks and accusations of being a postmodern composer. I don't give a damn. ${ }^{6}$

Ligeti's latest music refers to music and approaches of the past in some ways, but to label it as postmodernist is misleading. To develop a full understanding of why Ligeti (like some of his contemporaries) has shifted towards a more conservative approach, it is necessary to consider briefly the compositional techniques he used in the $1960 \mathrm{~s}$.

Ligeti's music from the early 1960s shows a complete destruction of traditional compositional means. For example in a work like Atmosphères for orchestra (1961), melody, harmony and rhythm are all practically excluded in favour of texture and timbre. The harmony largely consists of saturated semitone clusters; there is no clearly recognizable melody. This music does show a type of polyphony described by Ligeti as Mikropolyphonie, but this results in a complex

\footnotetext{
4 'A Conversation with György Ligeti', p.14.

s Ibid., p.14.

6 Ibid., p.15.
} 
interweaving texture, rather than audible counterpoint. ${ }^{7}$ What can be observed in Atmospheres is a 'razing to the ground' of past traditions and building a compositional edifice with completely new foundations.

Throughout the 1960s it is possible to identify in Ligeti's music a refining of the techniques found in Atmospheres and Apparitions for orchestra (1958-9). Mikropolyphonie becomes a much more varied and subtle device, controlling the whole process and evolution of a work in a similar way to the compositional processes found, for example, in the music of Steve Reich. Lontano for orchestra (1967) and Lux Aeterna for voices (1966) are particularly significant examples of this refined process. ${ }^{8}$ There is less use of the broad 'brush-stroke' of texture and timbre, and more reliance on arhythmic canons. The aural result consists of a slowly shifting cluster, starting from a unison note and gradually expanding, rather in the way a fertilized egg develops, by splitting each cell into two, and then each new cell splits again, ad infinitum. See Ex.1, from Lux Aeterma, showing the background clusters: individual parts move at a quicker pace than the surrounding texture, bringing them forward in the perspective of the musical landscape. Even in the enormous web-like structures of Lontano there are always instruments and motifs which are more apparent to the ear; this is almost a chance-like function of Ligeti's orchestration. If all the instruments (or voices) are marked $p p$, it is inevitable that the balance will not be completely equal (indeed this unevenness of balance is almost essential to the music, otherwise the texture could become extremely bland and featureless). Each performance/recording of Lontano (or other similar works) is therefore quite distinct, because the 'foreground' parts will never be the same; it is not simply a matter of interpretation but is a result of the musical language. ${ }^{9}$

The shift towards melodic writing becomes even more clear in Ligeti's Chamber Concerto (1969-70) and in Melodien for orchestra (1971). In the former work, the second movement shows the solo instruments (horn, trombone, and oboe d'amore) taking parts of the surrounding background texture and placing them in the foreground

Ex.1 bars 1- 12

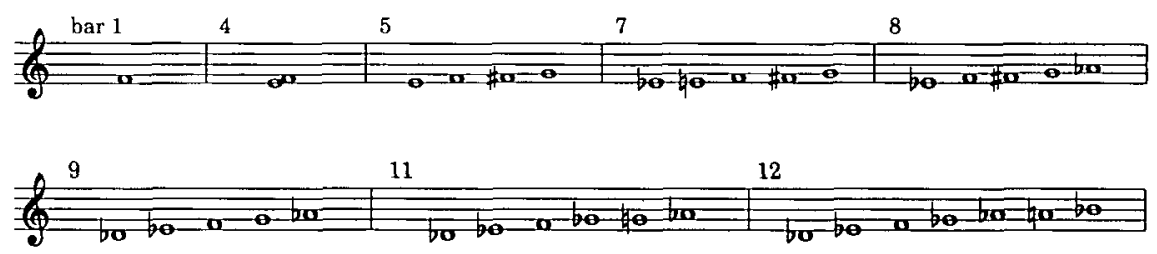

The background shifting clusters do not consist of simple superimposed semitones, but also have whole-tone and minor-third gaps. There is therefore a greater sense of 'harmony', although not of traditional harmonic progressions, as each harmony dissolves into the next. This technique can be clearly seen in the Etude 'Harmonies' for organ (1967) which has the visual appearance of a reduction to the background clusters of one of the micropolyphonic works.

It is possible to perceive a shift towards more melodic formations, even in polyphonic works like Lux Aeterna. This feature can be heard where

\footnotetext{
${ }^{7}$ Mikropolyphonie consists of many canonic lines superimposed but with different rhythms, producing a tight web-like texture with a background cluster which slowly evolves.

${ }^{8}$ Ligeti continues to use canonic structure in later works such as Magyar Etüdök (1983) although this uses a more traditional rhythmic canon. The structure and process in these pieces are explored in detail in the following article: Luminita Aluas, 'Visible and Audible Structures: Spatio-Temporal Compromise in Ligeti's Magyar Etüdök', Tempo 179, December 1992, pp.7-17.
}

by slowing them down and increasing the dynamic; see Ex.2. Here the Mikropolyphonie has been magnified so that the lyricism of the individual lines is audible. It shows that Ligeti's style has evolved into a more expressive and arguably subjective language. Ligeti himself says concerning Melodien:

... the melodically shaped parts retain their individuality, they move simultaneously at varying speeds and possess a melodic and rhythmic line of their own, varying from and independent of the other parts. In this way melodic shape, that forbidden fruit of modern music, can to some extent be restored. ${ }^{10}$

This work was written in 1971; it is revealing to observe how often Ligeti has 'bitten' into the

\footnotetext{
${ }^{9}$ A similar phenomenon can be seen in works like Penderecki's Threnody for the victims of Hiroshima, which uses chance-like textures, although it is much more clearly aleatoric in Penderecki's case.

${ }^{10}$ György Ligeti, Ligeti in Conversation, London, Eulenberg, 1983, p.137.
} 


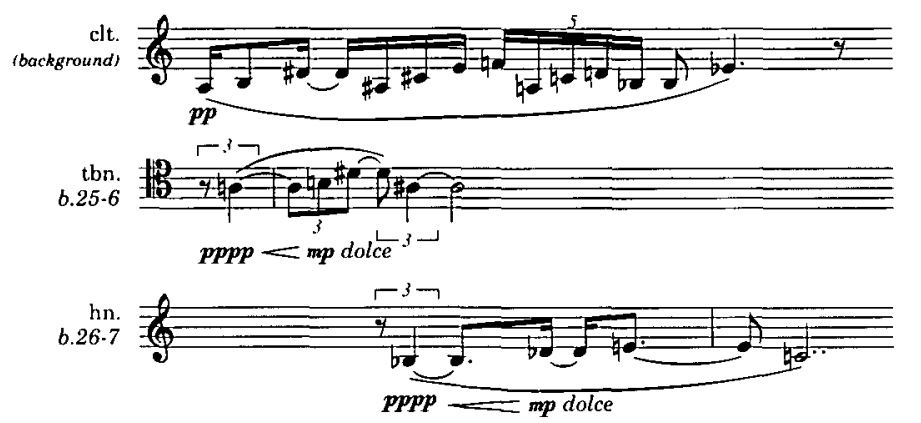

apparently 'forbidden fruit' of melody over the next 25 years.

In his works of the early 1960 s, however, there is a sense in which Ligeti destroyed the traditional elements of music such as harmony, melody, and rhythm, to allow himself to focus on the parameters of texture and timbre. ${ }^{11}$ It is hardly surprising that once his experiments in the use of those parameters had been fully explored, he needed to move on to new concerns. As Ligeti states:

... creating something that already exists is not interesting for me. If something new has been tried out and a result has emerged from it, it is not worth making the same experiment again. ${ }^{12}$

This meant rediscovering elements he had previously avoided: harmony; melody; rhythm; and finally thirds, sixths, triads and tonal/modal implications. This 'rediscovery' is not a simple return to a traditional view of these elements, but an examination of them in the light of his earlier discoveries.

It is thus misleading to suggest that Ligeti's latest works are postmodernist or 'retro': he is not trying to 'rediscover the past', rather he is trying to discover new ways of treating universal elements of music. He puts it like this:

Now I have the courage to be 'old-fashioned'. I don't want to return to the 19th century, but I'm no longer interested in such categories as avant garde, modernism or atonality ${ }^{13}$... I hate neo-Expressionism and I can't stand the neo-Mahlerite and neo-Bergian affectations, just as I can't stand post-modern architecture. ${ }^{14}$

The main generalized characteristics of modernist harmony are, usually, an avoidance of tonal implication and a fairly consistently high

\footnotetext{
11 This kind of musical experimentation would not have been allowed in Hungary in the 1950s.

${ }^{12}$ Ligeti in Conversation, p.94.

13 'A Conversation with György Ligeti', p.14.

14 Ibid., p.17.
}

dissonance. This can create an unnecessarily restricted harmonic palette in which many possible harmonies are taboo. What can be seen in Ligeti's later works, such as the Horn Trio (1983), Piano Concerto (1988) and Violin Concerto (1992), is an incredibly rich and wide range of harmony. As Taylor observes:

The harmonies [in Ligeti's later music] have been of four types:

1. Triads, major or minor in first inversion;

2. 'open-fifth fields', though not always arranged vertically in fifths;

3. $\{0,1,6\}$, which combines tritones, major sevenths, and fifths - also elaborations of this set such as $\{0,1,2,7\}$ or $\{0,1,3,6,7\}$ or a major triad with an added \#fourth;

4. Seventh chords - usually major, minor, diminished or half diminished in root position or inversion. ${ }^{15}$

Such a breadth of harmony creates for Ligeti a much more expressive harmonic language which is extended further by his use of microtonality or unusual tunings. These can be found in the Horn Trio, the Violin Concerto (especially when the ocarinas are used), Ramifications for Strings (1968-9), and Passacaglia ungherese for Harpsichord (1978).

The latter work uses mean-tone temperament, which allows the basic eight intervals of the work (major thirds and minor sixths) to be heard in just intonation. It is one of the first works to explore Ligeti's new ambiguous tonal style; the opera $L e$ Grand Macabre (1974-7) also explores tonality, but there it is driven by quotation and pastiche, rather than the forging of a new musical language. The Passacaglia is based on a succession of eight intervals, inverted at bar 5 , which form the framework for the passacaglia. These intervals are all major thirds and minor sixths (inversions of each other) and contain all 12 notes of the chromatic scale. Four pitches related by the interval of the perfect fourth (E, A, D, and $G$ )

${ }^{15}$ The Lamento Motif, p.75. 
appear twice and seem to create a shifting tonal centre. The progressions of the intervallic framework seem to imply C, D, G, and F, as fleeting tonal centres. ${ }^{16}$ Another feature is the lower voice, which outlines two chromatic clusters in a rather Webernesque manner.

Passacaglia Ungherese is Baroque in its textural sound world but becomes increasingly demented and distorted as the relatively simple and straightforward opening music disintegrates. It begins with a simple melodic line, added to the passacaglia at bar 5, which sometimes fits, and sometimes contradicts, the underlying harmonic implication. Generally the piece becomes denser and more contrapuntal before appearing to 'break down' on the final page; rather like one of Ligeti's movements based on machines and clocks which eventually self-destruct (for example, the third movement of his Chamber Concerto). The final chord in Passacaglia consists of a clear E major triad, but this does not sound as a tonic, and the tonality remains enigmatic throughout. This ambiguous approach to quasi-tonal harmony allows Ligeti to 'play' with the listener's expectations. The listener never feels completely on firm tonal land because the harmonic background of the music is continually twisting and turning.

In Ligeti's next work, the Horn Trio, it is possible to see continuations of some of the ideas contained in the Passacaglia. Ligeti consistently uses thirds, sixths and triads throughout the Horn Trio (see Ex.3) combined with other more dissonant and atonal harmonies. The work never shows a clear sense of tonality other than in the most fleeting sense, and clear triadic formations are subverted by the other parts; see Ex.4.

In the second movement the ostinato in the left hand of the piano seems to imply a combination of the keys of $\mathrm{C}$ and $\mathrm{G}$ flat - a rather Bartókian device - but the melodic right hand is freely chromatic, albeit within local modal regions; see Ex.5.

The other link between the Passacaglia and the

Ex.3 bars $1-5$ 1st Movement Andantino

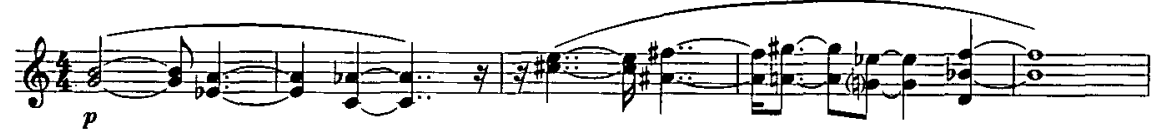

Ex.4 2nd Movement bars $155-7$

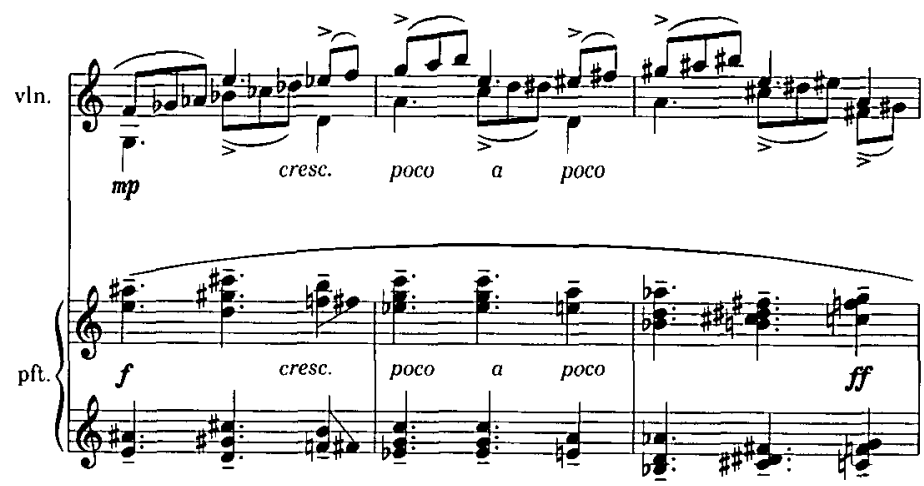

Ex.5 2nd Movement bars $15-18$

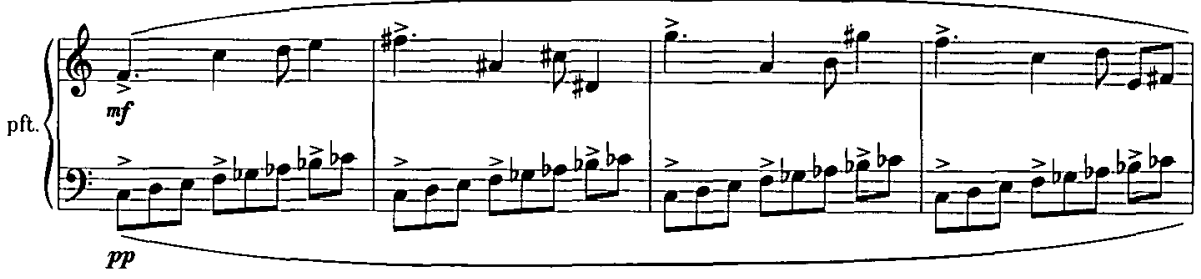

${ }^{16}$ The shifting cadences are reminiscent of the opening of Beethoven's First Symphony, which has a similarly disorienting effect.
Horn Trio is that the last movement of the latter work is also a passacaglia: one whose subject is five bars in length and which provides the 
emotional and expressive climax of the work. It is also the most overtly lyrical movement, using extensively a figure described by Ligeti as the 'Lamento motif ${ }^{17}$ (see Ex.6). Steven Taylor suggests this is a fundamental melodic 'signal' in Ligeti's later works such as the second movement of the Piano Concerto and the sixth Piano Study (1985). ${ }^{18}$ According to Jeffery Bossin this motif is based on the funeral laments of the women of Siebenbürgen. ${ }^{19}$ clear-cut, showing an apparent combination of Balkan and Latin-American rhythms. As Ligeti states:

For a great many years I have been interested in asymmetrical rhythms, which Bartòk called Bulgarian rhythms. . . These asymmetrical rhythmic formations have been very much in line with my search for new rhythmic solutions. . [Hungarian Rock] has a little of the influence of Latin American rhythm. But it was derived from the commercial semi-folklore of South

Ex.6 4th Movement bars $51-3$

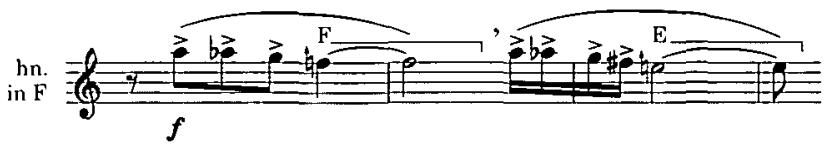

This significant figure is characterized by falling semitones interspersed with tones, and in the Horn Trio it also includes the horn's natural harmonics, causing a shift in the size of the intervals.

The use of the chromatic line in Ligeti's music is not new, as it can be found in all his 1960s works, especially the Second String Quartet which uses octave displacement to disguise the fact. What is new in the Horn Trio is the way it is used expressively, as an emotionally charged statement. There is a communication of deep melancholy and seriousness, rarely found with such intensity up to this point in his output.

Another element which has evolved is Ligeti's use of rhythm; much of his music has become more clearly pulse-driven from the late 1970s onwards. In the 'Farbenmusik' 20 of the 1960s, including such works as Lontano and Atmospheres, it is very difficult to perceive any sense of beat or barline; the music is purposefully constructed to avoid a sense of pulse. Where a pulse can be heard, for example in the 'mechanico' 21 movements such as the third movements of the Chamber Concerto and the Second String Quartet, it consists of a number of conflicting and interfering pulses which confuse the total rhythmic result.

In Hungarian Rock (Chaconne) for harpsichord (1978), the rhythmic language is completely

\footnotetext{
${ }^{17}$ The Lamento Motif, p.3.

${ }^{18}$ Ibid., p.3.

19 Jeffrey Bossin, 'György Liget's New Lyricism and the Aesthetic of Currentness: The Berlin Festival's Retrospective of the Composer's Career', Current Musicology, 37/38, 1984, p.237.

${ }^{20}$ Literally 'colour music', where texture and timbre are more important than the traditional parameters of music.

${ }^{21}$ Based on clock-like, layered mechanisms.
}

and Central America and from pop music and jazz. ${ }^{22}$

The basic rhythm of Hungarian Rock is divided into $5 / 8$ plus $4 / 8$, which creates a constant fourbar background ostinato in the left hand for the right hand to play against. This has a clear relationship with Passacaglia in terms of the structural model and harmonic language, but the rhythmic elements are quite different. In Hungarian Rock, rhythm is the main driving force; Passacaglia does not have the same distinctive rhythmic energy, although it does have a 'clock-like forward motion.

The increased emphasis of pulse and clear-cut rhythms can be observed in a number of subsequent works. In the Horn Trio, the second movement explores asymmetric rhythms by shifting the accent within the bars of 8 quavers to create contrasting groupings such as $3+3+2$, $3+2+3,4+4$, or $2+3+3$; but the underlying quaver pulse is never in doubt. In the third movement, Alla Marcia, the underlying pulse is fairly clear, although Ligeti continually confuses or disrupts the listener by displacing the beat, creating an erratic 'off-beat' and slightly ironic 'march'.

Ligeti's interest in rhythm has extended to the structures of Sub-Saharan music, and also the player-piano studies of Nancarrow, which create multilayered and multi-tempo lines. A simple example of the former is in the third movement of the Piano Concerto, where Ligeti builds up two layers, articulating three crotchets against four dotted quavers (Ex.7). Far more complex combinations of different simultaneous tempi can be seen in the sixth Piano Study - but as Keith Potter points out, these different speeds can be

${ }^{22}$ Satory, S., 'An Interview with György Ligeti in Hamburg', Canadian University Music Review, 10, 1990, p.109. 


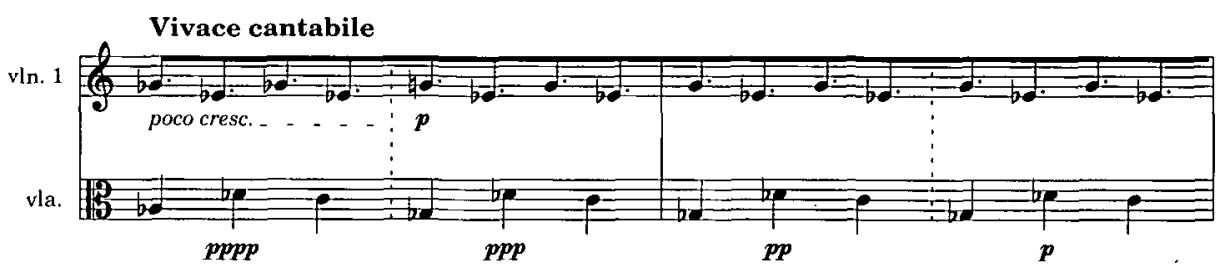

more clearly heard when they are performed by separate instrumentalists/singers such as in the Nonsense Madrigals (1988). ${ }^{23}$ In general it can be seen that rhythm has become more of a foreground component of Ligeti's language, and has a clear connexion with Bartók's use of rhythm.

Ligeti's approach to structure has evolved towards the use of shapes which are more preformed and perhaps traditional in nature. Examples include the use of passacaglia structures in the finale of the Horn Trio, the Passacaglia Ungherese, and the fourth movement of the Violin Concerto; and also the use of a simple ternary structure in the first three movements of the Horn Trio. This approach is very different to that in works like Lontano, where the structural model has an almost improvisational character with very little repetition of earlier material. The structures of his music up to Le Grand Macabre have a high degree of unpredictability about them; the listener is never sure what is going to happen next. A good example is in the first movement of the Chamber Concerto at bar 38, where a solo violin trill opens up into a huge $\mathrm{Eb}$ in several octaves, apparently on a completely new tonal, registral, and structural dimension. The unpredictability in the direction of the musical discourse continues in Ligeti's latest music, but there are also many examples showing a more traditional approach to structure, and a greater use of repetition than in his works from the 1960s.

It was almost inevitable that Ligeti's musical language would become more conservative after the sonic adventures and experiments of the 1960s. When melody, harmony, rhythm and structure have been atomized, and apparently pulled apart, the next step would seem to be gradually to reintegrate the elements into the new musical landscape. Where Ligeti differs from the postmodernists is that his 'rediscovery' of past materials illuminates them in a new and original way, whereas much of what is classified as postmodernist music seems to be attempting to breathe life into long-dead musical corpses. Ligeti's music is postmodern in the sense that it goes beyond modernism; but it does not show the sentimentality or backward-looking quality of much of what is classified as postmodernist music. He has observed:

We live in an age of artistic pluralism. While modernism and even the experimental avant-garde are still present, 'post-modern' artistic movements are becoming more prevalent. 'Pre-modern', however, would be a better word to describe these movements, for the artists who belong to them are interested in the restoration of historical elements and forms. ${ }^{24}$

Ligeti's recent music shows that it is important for him to continue to explore Mankind's relationship with sound and structure, which implies looking to the future and not wallowing in the self-indulgence of the 'musical museum' (whether this 'museum' consists of the experimentalism of the 1960s or the Romanticism of Wagner or Mahler). Like Stravinsky's music, all Ligeti's music has a distinctive individuality irrespective of the particular stylistic/compositional approach he has used. This is the sign of a musician who still has meaningful ideas to communicate to our society.

Music examples $\oplus$ copyright by Schott \& Co. Ltd. 
Universal Edition Ltd

48 Great Marlborough Street

London W1V 2BN

Recent scores from

\section{Luciano Berio}

COMPASS (1994)

Ballet-Recital for piano and orchestra

RE-CALL (1995)

for large ensemble

NOTTURNO (1995)

string quartet No 3 realised for string orchestra

SEQUENZA XII (1995)*

for bassoon

SEQUENZA XIII (1995/96)

for accordion

KOL-OD (Chemins VI) (1995/96) *

for trumpet and chamber orchestra

*UK premiere on October 10th 1996

London Sinfonietta conducted by Markus Stenz

with Gabriele Cassone and Pascal Gallois 